\section{Australian Journal of \\ Crop Science}

AJCS

ISSN:1835-2707

AJCS 13(01):105-114 (2019)

doi: 10.21475/ajcs.19.13.01.p1388

\title{
Growth and nutrition of Pitombeira (Tasilia esculenta Radlk) seedlings in different substrates and biofertilizer application
}

\author{
Adailza Guilherme Cavalcante ${ }^{1}$, Alian Cássio Pereira Cavalcante ${ }^{2 *}$, Antônio Gustavo de Luna Souto ${ }^{2}$, \\ José Flavio Cardoso Zuza ${ }^{3}$, Murielle Magda Medeiros Dantas ${ }^{4}$, Raunira Costa Araújo ${ }^{4}$
}

${ }^{1}$ Paulista State University, Department of Plant Science, Jaboticabal, São Paulo, Brazil

${ }^{2}$ Federal University of Viçosa, Department of Plant Science, Viçosa, Minas Gerais, Brazil

${ }^{3}$ Federal University of Paraíba, Department of Soil and Rural Engineering, Areia, Paraíba, Brazil

${ }^{4}$ Federal University of Paraíba, Department of Agriculture, Bananeiras, Paraíba, Brazil

\section{*Corresponding author: cassio.alian216@gmail.com}

\section{Abstract}

The pitombeira (Tasilia esculenta Radlk.) is a fruit native to Brazil, which is being exploited in an extractive way. To get agronomic information, such as the formation of mudase to be used in future commercial plantations, therefore, the objective was to evaluate the initial development and accumulation of nutrients in pitombeira seedlings submitted to different organic substrates and biofertilizer application in the soil. The experimental design was in randomized blocks, with a factorial arrangement of $4 \times 2$ and five replications. The treatments corresponded to four substrates (W, control; CS, commercial substrate; RFV, composite of fruit and vegetable remnants of a university restaurant; SIP, residues of industrialized products) in the substrate without and with Supermagro biofertilizer. Ninety days after sowing, the plant height, stem diameter, total dry mass, Dickson Quality Index, and leaf content in macronutrients were evaluated. The use of residues of fruits and vegetables (RFV) and residues of industrialized products (SIP) is recommended for the composition of submetry of pitombeira because these contribute to the greater growth of pitombeira seedlings. The addition of organic residues increases the quality of pitombeira seedlings having higher quality as biofertilizer treatments. Commercial substrate (CS) increases nitrogen and potassium terrors for substrates with fruit and vegetable residues (RFV), and the residues of industrialized products (RPI) used for the propagation of pitombeira seedlings can be recommended for the production of seedlings, because they increase the leaf content of phosphorus, calcium, magnesium, and sulfur.

Keywords: Leaf nutrients, organic matter, fruticulture, propagation, Talisia esculenta Radlk.

\section{Introduction}

The pitombeira (Tasilia esculenta) is a fruit of the species belonging to the Sapindaceae family, native to the Amazon region and found within dense forests, floodplains, and transition valleys of several regions in Brazil, mainly in transition areas of Cerrado and Caatinga of the North, Northeast, Southeast, and Central West Brazil (Sena et al., 2016). This species is a fruit explored through extractivism or in domestic orchards, to gather information by agronomic techniques for use in future commercial plantations, with relevance in the production of seedlings with a high-quality standard (Pereira et al., 2011; Souza et al., 2016). The pitombeira fruit is attractive and accepted by consumers because of its pleasant taste and high content of vitamins and minerals.

The formation of seedlings in pitombeira is, generally, a process that requires care because of it being a delicate stage; however, information about its propagation (Melo Filho et al., 2015) is lacking. For the production of seedlings with high-quality standards, the farmer should define appropriate sites, a good initial management of seedling growth, and define which substrate provides physical quality for the full development of the root and chemical system to provide nutrients for the proper and uniform development of plants (Castro et al., 2012).

The use of industrial waste in the composition of substrates is a practice that has been the subject of several researches with the objective of minimizing the impacts generated by them and contributing to the reduction of the production cost of the substrate (Castro et al., 2012; Santos et al., 2014). For Kratz et al. (2015), the advancement of seedling production technology has led to the gradual replacement of subsurface soil by other materials, mainly renewable ones, such as agro-industrial waste and organic compounds from commercial locations and domestic. With the increase in the production of seedlings throughout the national territory, it is necessary to use these residues as a substrate for initial plant growth, avoiding contamination of soil and groundwater when discarded in the environment.

According to Antunes et al. (2016), although the addition of conventional fertilizers contribute to soil fertility and rapid availability to plants, the use of organic fertilization improves soil biotic conditions, thereby promoting plant growth. 
Identifying the amount of nutrients absorbed and the nutritional status of the plant can help in the formulation of substrates with a balanced amount of fertilizer that contribute to the adequate formation of seedlings that will be taken to the field, because adequately nourished plants will have a greater chance of higher yields and better quality (Augostinho et al., 2008).

For the nutritional diagnosis of cultivated plants, foliar tissue is the most indicated, considering that it is in this organ where the main metabolic reactions of the plant occur (Taiz et al., 2017). Faced with the lack of information on the formation of seedlings and nutrition of this species, the objective was to evaluate the growth and accumulation of nutrients in pitombeira seedlings submitted to different organic substrates and biofertilizer application in the soil.

\section{Results}

\section{Variables of growth and quality of pitombeira seedlings}

The highest values of stem height of the seedlings were observed in the substrate treatments with residues of fruits and vegetables and substrate with the remains of industrialized food, both from a university restaurant, with values of 15.43 and $15.2 \mathrm{~cm}$, respectively (Fig $1 \mathrm{~A}$ ). Following the order of the best results, the substrates of RFV and SIP were higher by $10.91 \%$ and $9.11 \%$ in relation to the commercial substrate and $21.94 \%$ and $19.96 \%$ in the control. A similar tendency to the stem diameter showed that the Supermagro biofertilizer did not statistically influence the height of the pitombeira seedlings, where the plants had a mean height of 14.2 and $14.6 \mathrm{~cm}$, respectively, in the substrate with or without the organic input (Fig 1B).

The highest values of stem diameter of the pitombeira seedlings were obtained in the substrate containing RFV, with a value of $3.82 \mathrm{~mm}$ and in comparison to the control, the increment was $13 \%$ (Fig 2A). The substrates containing SIP and CS cannot be differentiated between each other with regard to the stem diameter, presenting values of 3.59 and $3.57 \mathrm{~mm}$, respectively. The application of biofertilizer provided no significant difference (Fig $2 \mathrm{~B}$ ).

A similar behavior in the height of the seedlings was observed for the total dry mass of the pitombeira plants, wherein the substrate containing the rest of the fruits and vegetables and the substrate with the rest of industrialized products presented the best results (Fig $3 \mathrm{~A}$ ). Plants grown with these substrates obtained an MST of 35.9 and $33.1 \mathrm{~g}$, respectively, at increments of $40.26 \%$ and $29.31 \%$. However, the application of the biofertilizer to the substrate did not affect the accumulation of the total dry mass of the pitombeira plants (Fig 3B), where the values were 30.3 and $31.7 \mathrm{~g}$, respectively, in the treatments with or without the organic input. This situation may prove that the substrate volume was insufficient and might promote physical stress to the adequate growth of the seedlings

From the results observed in Fig. 4A, it was verified that the highest-quality indices of Dickson were obtained in the commercial substratum, substrates with residues of fruits and vegetables from a university restaurant, and the substrates containing industrial products. The DQI values were $1.74,1.66$, and 1.81 , respectively, in CS, RFV, and SIP and did not differ among themselves in the means test; the control presented an average value of 1.34. The Supermagro biofertilizer provided better seedling formation because of the higher value of Dickson quality index (1.73) compared with the soil without organic input (1.55), with a $10.4 \%$ increase with biofertilizer (Fig. 4B).

\section{Nutritional variables in pitombeira seedlings}

The highest nitrogen contents were observed in the commercial substratum, regardless whether or not there is application of Supermagro biofertilizer, with com values of 23.99 and $26.33 \mathrm{~g} \mathrm{~kg}^{-1}$ at increments of $47.92 \%$ and $29.67 \%$, respectively (Table 2 ). The substrates with the industrialized vegetable and food residues did not differ among them as to whether or not there is application of the organic input, presenting averages of 23.7 and $22.9 \mathrm{~g} \mathrm{~kg}^{-1}$ in the soil with biofertilizer and 22.6 and $21.9 \mathrm{~g} \mathrm{~kg}^{-1}$ in the soil without biofertilizer.

A behavior similar to leaf nitrogen content was seen in the potassium contents of the leaves of pitombeira seedlings, where the plants were cultivated in a commercial substratum that had the highest values of $\mathrm{K}$ (18.02 and 18.78 $\mathrm{g} \mathrm{kg}^{-1}$, respectively) in the treatment with and without biofertilizer (Table 2). The RFV substrate had a mean content of $11.66 \mathrm{~g} \mathrm{~kg}^{-1}$ owed by the RPI with $8.90 \mathrm{~g} \mathrm{~kg}^{-1}$ and the control with $8.86 \mathrm{~g} \mathrm{~kg}^{-1}$.

The highest leaf phosphorus content was observed in the substrate with fruit and vegetable residues (1.09 $\mathrm{g} \mathrm{kg}^{-1}$ ), commercial substrate and residue of industrial products with Supermagro biofertilizer $\left(1.13 \mathrm{~g} \mathrm{~kg}^{-1}\right)$, as shown in Table 4 . On average, $\mathrm{P}$ levels were observed in the following order: $\mathrm{SIP}>\mathrm{RFV}>\mathrm{CS}>\mathrm{W}$, with values of $1.11,1.06,1.03$, and $0.80 \mathrm{~g}$ $\mathrm{kg}^{-1}$, respectively. The use of the residues of industrialized products in the treatments with and without biofertilizer and in the substrate with fruit and vegetable residues promoted the highest $\mathrm{Ca}^{2+}$ leaf contents, with values of 22.56, 22.67, and $23.06 \mathrm{~g} \mathrm{~kg}^{-1}$ (Table 2). As observed in phosphorus, the highest calcium contents in the pitombeira leaves were in the same sequence of substrates (SIP> RFV > CS> W). The calcium contents were obtained from the substrates of SIP with and without biofertilizer and in RFV without the application of the input. The application of the biofertilizer shows a difference wherein the substrates with the input obtained the lowest accumulation of this nutrient (Table 2). The highest levels of foliar magnesium in the pitombeira seedlings were obtained in the substrates formulated with the residues collected in a university restaurant, regardless of the application of the organic input to the soil, with values of 4.39 and $4.41 \mathrm{~g} \mathrm{~kg}^{-1}$ in the substrates with RPI and 5.22 and $4.47 \mathrm{~g} \mathrm{~kg}^{-1}$ in the substrates with RFV, respectively, in the soil with and without biofertilizer (Table 2). On average, the order in the Mg leaf contents were as follows: $\operatorname{RFV}\left(4.84 \mathrm{~g} \mathrm{~kg}^{-1}\right)>\operatorname{SIP}\left(4.40 \mathrm{~g} \mathrm{~kg}^{-1}\right)$ $>\mathrm{CS}\left(3.14 \mathrm{~g} \mathrm{~kg}^{-1}\right)>\mathrm{W}\left(3.10 \mathrm{~g} \mathrm{~kg}^{-1}\right)$. The use of residues of industrial products and commercial substrates, independent of the application of the biofertilizer, promoted higher levels of leaf sulfur in pitombeira seedlings, with the order of $S$ values being RPI $>\mathrm{CS}>\mathrm{RFV}>\mathrm{W}$ (Table 2 ). The highest values were 3.66 and $4.03 \mathrm{~g} \mathrm{~kg}^{-1}$ of $\mathrm{S}$ in the substrate with RPI and 3.60 and $3.78 \mathrm{~g} \mathrm{~kg}^{-1}$ of $\mathrm{S}$ in CS in the soil without and with the organic input, respectively.

\section{Discussion}

According to the chemical analysis of the substrates used (Table 1), the best results for the stem height of the 
Table 1. Chemical analysis of fertility of compounds and biofertilizer.

\begin{tabular}{|c|c|c|c|c|c|c|c|c|c|c|c|c|c|}
\hline Sample & $\begin{array}{r}\mathrm{pH} \\
\mathrm{H}_{2} \mathrm{O}(1: 2,5)\end{array}$ & $P$ & $\mathrm{~K}^{+}$ & $\mathrm{Na}^{+}$ & $\mathrm{H}^{+}+\mathrm{Al}^{3+}$ & $\mathrm{Al}^{3+}$ & $\mathrm{Ca}^{2+}$ & $\mathrm{Mg}^{2+}$ & SB & СTC & V & $\mathrm{m}$ & MOS \\
\hline & & & $\mathrm{mg} / \mathrm{dm}^{3}$ & & & & $-\cdots$ & $-\overline{------c}$ & $\mathrm{~lm}^{3}-\cdots$ & -------- & & ---\%--- & $\mathrm{g} / \mathrm{kg}$ \\
\hline$w$ & 5.42 & 8.68 & 60.00 & 0.17 & 2.15 & 0.05 & 1.50 & 1.30 & 3.13 & 5.27 & 59.32 & 1.57 & 5.68 \\
\hline CS & 7.20 & 230.21 & 980.50 & 1.80 & 3.51 & 0.00 & 7.75 & 1.95 & 14.01 & 17.52 & 79.96 & 0.00 & 86.90 \\
\hline RFV & 7.07 & 301.39 & 4500.00 & 2.00 & 3.96 & 0.00 & 12.40 & 2.90 & 28.81 & 32.77 & 87.92 & 0.00 & 103.96 \\
\hline SIP & 6.00 & 305.21 & 3800.00 & 6.96 & 7.75 & 0.40 & 8.50 & 4.20 & 29.38 & 37.13 & 79.11 & 1.34 & 119.58 \\
\hline \multirow{3}{*}{ Biofertilizer } & & $\mathrm{pH}$ & $\mathrm{N}$ & & $\mathrm{P}$ & $\mathrm{K}$ & $\mathrm{B}$ & \multirow{2}{*}{\multicolumn{4}{|c|}{ 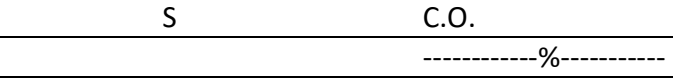 }} & \multirow[t]{2}{*}{ MOS } & \\
\hline & & \multicolumn{5}{|c|}{ - } & & & & & & & \\
\hline & & 3.27 & \multicolumn{2}{|l|}{15.93} & 0.40 & 0.52 & \multicolumn{2}{|c|}{153.58} & 10.47 & 47.25 & \multicolumn{2}{|c|}{81.46} & \\
\hline
\end{tabular}

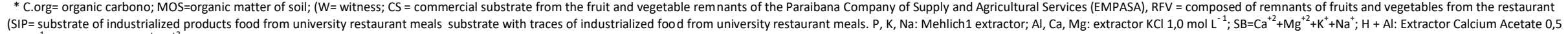

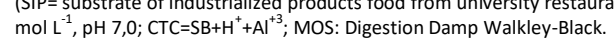
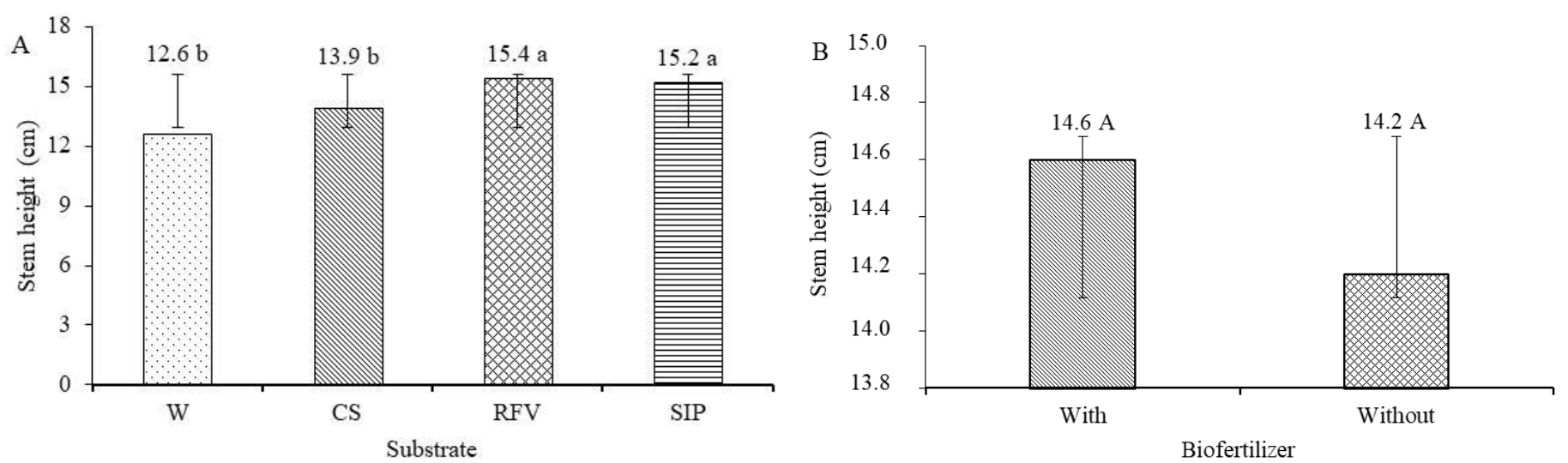

Fig 1. Stem height in pitombeira molting as a function of substrate composition (A) and application of biofertilizer in soil (B). 
Table 2. Nitrogen, phosphorus, potassium, calcium, magnesium and leaf sulfur contents in pitombeira seedlings submitted to different organic substrates with presence and absence of biofertilizer via soil.

\begin{tabular}{|c|c|c|c|}
\hline \multirow{3}{*}{ Substrate } & \multicolumn{2}{|c|}{ Biofertilizer } & \multirow{3}{*}{ Average } \\
\hline & With & Without & \\
\hline & \multicolumn{2}{|c|}{ Nitrogen $\mathrm{g} \mathrm{kg}^{-1}$} & \\
\hline W & $18.50 \mathrm{cA}$ & $17.80 \mathrm{cA}$ & 18.1 \\
\hline CS & $23.99 \mathrm{aB}$ & $26.33 \mathrm{aA}$ & 25.1 \\
\hline RFV & $22.60 \mathrm{bB}$ & $23.70 \mathrm{bA}$ & 23.1 \\
\hline SIP & $21.90 \mathrm{bB}$ & $22.90 \mathrm{bA}$ & 22.5 \\
\hline Average & 21.7 & 22.7 & - \\
\hline $\mathrm{CV}(\%)$ & & & 3.20 \\
\hline \multirow{3}{*}{ Substrate } & \multicolumn{2}{|c|}{ Biofertilizer } & \\
\hline & With & Without & Average \\
\hline & \multicolumn{2}{|c|}{ Phosphorus $\mathrm{g} \mathrm{kg}^{-1}$} & \\
\hline W & $0.87 \mathrm{cA}$ & $0.74 \mathrm{bB}$ & 0.80 \\
\hline CS & $0.95 \mathrm{cB}$ & $1.13 \mathrm{aA}$ & 1.03 \\
\hline RFV & $1.03 \mathrm{bA}$ & $1.09 \mathrm{aA}$ & 1.06 \\
\hline SIP & $1.13 \mathrm{aA}$ & $1.08 \mathrm{aA}$ & 1.11 \\
\hline Average & 0.99 & 1.00 & - \\
\hline $\mathrm{CV}(\%)$ & & & 5.95 \\
\hline \multirow{3}{*}{ Substrate } & \multicolumn{2}{|c|}{ Biofertilizer } & \\
\hline & With & Without & Average \\
\hline & \multicolumn{2}{|c|}{ Potassium $\mathrm{g} \mathrm{kg}^{-1}$} & \\
\hline W & $9.37 \mathrm{cA}$ & $8.35 \mathrm{cA}$ & 8.86 \\
\hline CS & $18.78 \mathrm{aA}$ & $18.02 \mathrm{aA}$ & 18.40 \\
\hline RFV & $10.69 \mathrm{bA}$ & $11.64 \mathrm{bA}$ & 11.16 \\
\hline SIP & $8.63 \mathrm{cA}$ & $9.18 \mathrm{cA}$ & 8.90 \\
\hline Average & 11.87 & 11.8 & - \\
\hline $\mathrm{CV}(\%)$ & & & 6.79 \\
\hline \multirow{3}{*}{ Substrate } & \multicolumn{2}{|c|}{ Biofertilizer } & \\
\hline & With & Without & Average \\
\hline & \multicolumn{2}{|c|}{ Cálcium $\mathrm{g} \mathrm{kg}^{-1}$} & \\
\hline W & $12.34 \mathrm{dA}$ & $11.44 \mathrm{cA}$ & 11.89 \\
\hline CS & $16.03 \mathrm{cA}$ & $16.77 \mathrm{bA}$ & 16.40 \\
\hline RFV & 19.52 bB & $23.06 \mathrm{aA}$ & 21.29 \\
\hline SIP & $22.67 \mathrm{aA}$ & $22.56 \mathrm{aA}$ & 22.61 \\
\hline Average & 17.64 & 18.46 & - \\
\hline \multirow[t]{2}{*}{$\mathrm{CV}(\%)$} & & & 3.80 \\
\hline & \multicolumn{2}{|c|}{ Biofertilizer } & \\
\hline Substrate & With & Without & Average \\
\hline
\end{tabular}




\begin{tabular}{|c|c|c|c|}
\hline \multicolumn{4}{|c|}{ Magnesium g kg ${ }^{-1}$} \\
\hline W & $3.12 \mathrm{bA}$ & $3.08 \mathrm{cA}$ & 3.10 \\
\hline CS & $3.09 \mathrm{bA}$ & $3.19 \mathrm{cA}$ & 3.14 \\
\hline RFV & $4.47 \mathrm{aB}$ & $5.22 \mathrm{aA}$ & 4.84 \\
\hline SIP & $4.41 \mathrm{aA}$ & $4.39 \mathrm{bA}$ & 4.40 \\
\hline Average & 3.77 & 3.97 & - \\
\hline $\mathrm{CV}(\%)$ & & & 2.64 \\
\hline & \multicolumn{3}{|c|}{ Biofertilizer } \\
\hline & With & Without & Average \\
\hline$w$ & $2.65 \mathrm{dA}$ & $2.32 \mathrm{cB}$ & 2.48 \\
\hline CS & $3.78 \mathrm{bA}$ & $3.60 \mathrm{aA}$ & 3.69 \\
\hline RFV & $3.29 \mathrm{cA}$ & $3.32 \mathrm{bA}$ & 3.31 \\
\hline SIP & $4.03 \mathrm{aA}$ & $3.66 \mathrm{aB}$ & 3.85 \\
\hline Average & 3.44 & 3.22 & - \\
\hline $\mathrm{CV}(\%)$ & & & 4.73 \\
\hline
\end{tabular}
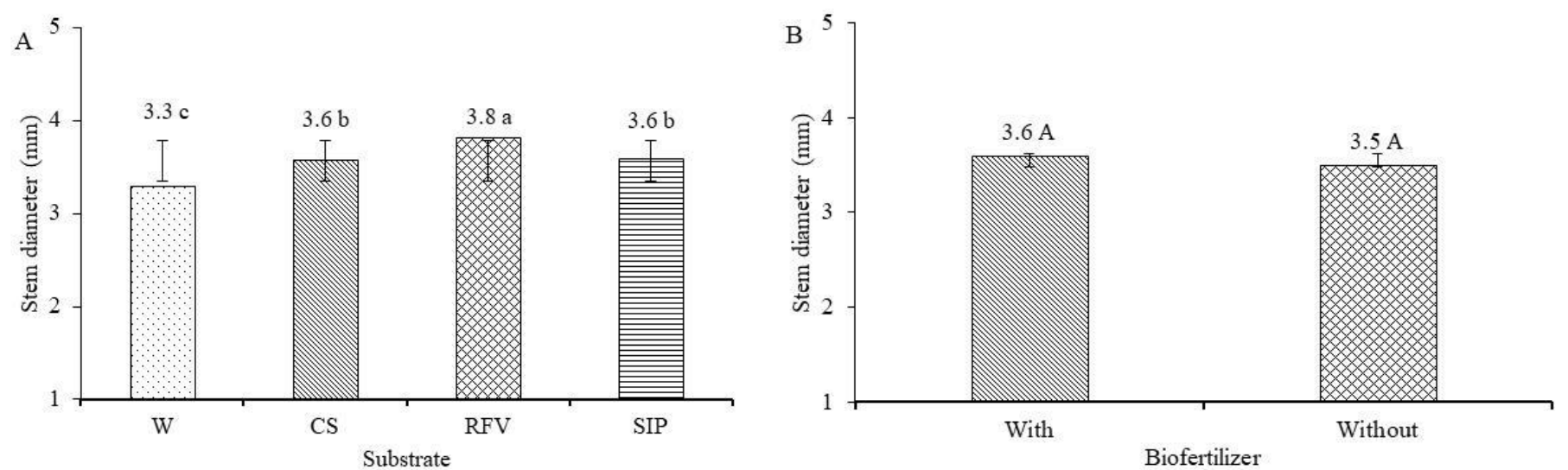

Fig 2. Stem diameter of pitombeira seedlings as a function of substrate composition (A) and application of biofertilizer in substrate (B). 

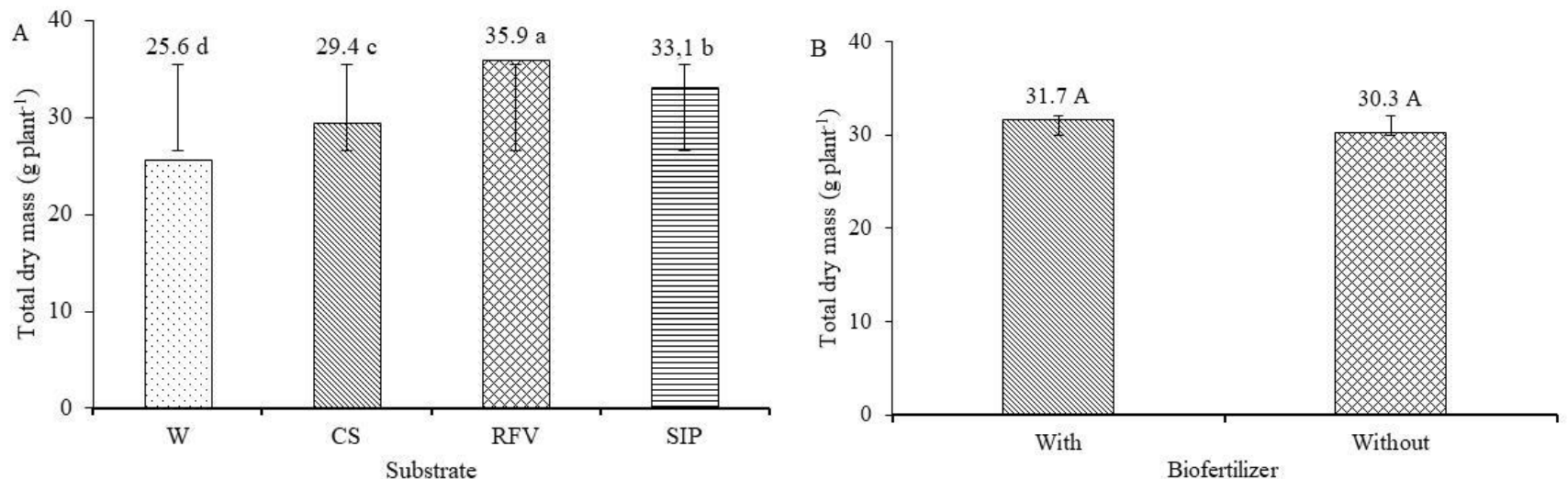

Fig 3. Total dry mass in pitombeira seedlings as a function of substrate composition (A) and biofertilizer application in soil (B).
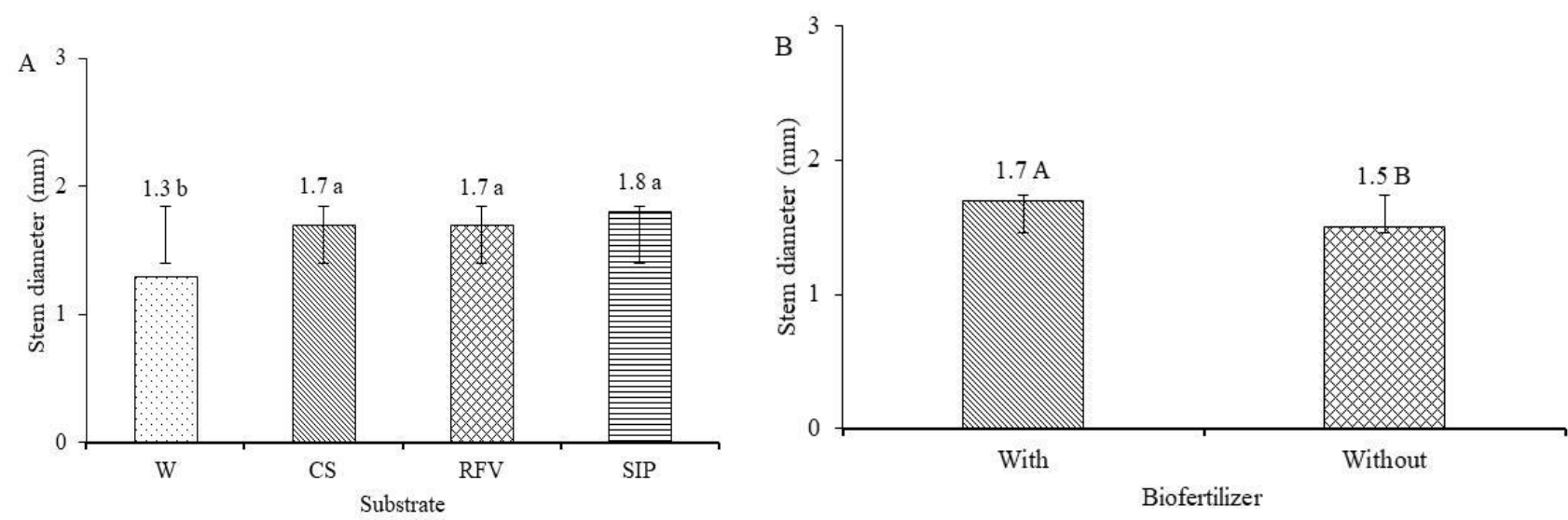

Fig 4. Dickson quality index of pitombeira seedlings as a function of substrate composition (A) and biofertilizer application in soil (B). 
seedlings were on substrates RFV and SIP, which might be related to the higher levels of $P, K$, and organic matter present in the residues. Potassium is a nutrient that does not participate in organic combinations and participates instead in the structural function, which causes it to be readily released when organic fertilizers are used (Kiehl, 2010; Magro et al., 2010). Antunes et al. (2016) evaluated the height of the seedlings in black acacia (Acacia mearnsii) and observed that the best value in this variable was obtained in the substrate with the application of vermicompost with the mixture of bovine manure and food residues, whose value was $22.6 \%$ superior to the control treatment.

The superiority of the values observed in the stem diameter for the pitomba seedlings in the substrate with the fruit and vegetable residue compound can be explained by the high phosphorus, potassium, calcium, and magnesium contents present in this substrate in relation to the other substrates evaluated, as shown in Table 1 . The organic compounds have the function of conditioning the soil, promoting the improvement of the physical properties of the substrate, such as increased porosity and soil structure improvement, contributing to root development (Prezotti, 2007). Rebouças Neto et al. (2016), using different concentrations of bovine biofertilizer in the initial corn growth, did not observe statistical difference. Probably, the results indicate that the chemical composition of the substrates together with the biofertilizer efficiently supplied the nutritional needs of the pitombeira seedlings.

The total dry mass accumulation of the pitombeira seedlings in the RFV substrate may be related to the amount of nutrient present in the substrate used compared with the other substrates. According to Taiz et al. (2017), phosphorus is a nutrient that promotes accumulation of biomass, especially in the early stages of growth. This is because the plant metabolism, $P$, is involved in the synthesis of phosphate sugars and phospholipids. According to Gonçalves et al. (2014), the higher the value, the more rustic the seedling will be, because they must be rigid at planting time, thus presenting greater resistance to the adverse conditions of the field, promoting greater survival, and minimizing replanting costs.

According to Vidal et al. (2006) and Soares et al. (2007), the Dickson quality index of the seedlings was satisfactory. The $D Q I$ is a good indicator of the quality of the seedlings that will be transplanted, because they concentrate in a single index with several morphological factors that allow to evaluate the robustness and the balance of the biomass In the interpretation of this parameter, the greater the value of the Dickson quality index, the better the quality of seedlings (Cavalcante et al., 2016a).

This index is used in the production of seedlings of forest species, and the same characteristics that make up the DQI are important for the production of fruit trees (Mesquita et al., 2015). The use of organic matter in the substrate for seedling production improves the physical and chemical conditions, resulting in a better substrate quality for seedlings production, as well as increasing the quality of the seedlings themselves (Oliveira et al., 2014).

Several relevant works have already been used this variable as developed by Trazzi et al. (2012) who obtained satisfactory results in the quality of Murraya paniculata seedlings, using proportions of sewage sludge and bovine manure as components of the substrates. Araujo et al.
(2014) used latosol as a substrate, which provided the highest DQI values in Rhizophora mangle L., Avicennia germinans (L.) Stearn, and Laguncularia racemosa (L.) Gaertn. Cavalcante et al. (2016b) used the organic composite in passion fruit seedlings.

The values observed for the nitrogen contents are higher than those of the other plant species studied, as described by Barros et al. (2013), who worked with different organic substrates in yellow passion fruit seedlings (Passiflora edulis Sims f. Flavicarpa Degene) and showed that the nitrogen accumulation was better in the substrate composed of soil and tanned bovine manure. Reis et al. (2015) obtained a value of $16.79 \mathrm{~g} \mathrm{~kg}^{-1}$ working with Dilodendron bipinnatum Radkl (Sapindaceae); whereas Antunes et al. (2016) found values varying between 9.73 and $12.44 \mathrm{~g} \mathrm{~kg}^{-1}$ using vermicompostos of different agroindustrial residues in black acacia (Acacia mearnsii Wild). The same authors have reported that the concentration of nutrients may be an indication of nutrition because of the different types of nutrient source applied.

The highest $P$ values in the pitombeira leaves are due to the observed chemical composition of the substrates (Table 1). Malavolta (1985) reported that phosphorus plays a key role in plant life by participating in energy-rich compounds, such as adenosine triphosphate (ATP). Oliveira e Hernandez (2008) studied eggplant culture in different substrates and obtained phosphorus contents of the seedlings, varying from 1.11 to $3.88 \mathrm{~g} \mathrm{~kg}^{-1}$. The highest concentrations of phosphorus in the aerial part of the eucalyptus seedlings were obtained in the treatment with $20 \%$ comprising sewage sludge $+80 \%$ carbonized rice husk (Rocha et al., 2013).

Potassium is a nutrient that, in addition to being involved in the growth of meristematic tissue, is important in maintaining the amount of water in plants (Jacoby et al., 1973). Aside from being an important enzymatic activator, it exerts a fundamental physiological function on plants, which is the regulation of stomatal closure and opening (Prado, 2008). Antunes et al. (2016) used different agroindustrial residues as substrate in the initial growth of Acacia mearnsii, the accumulated potassium contents in the dry matter of the leaves of the seedlings ranging from 6.41 to $13.79 \mathrm{~g} \mathrm{~kg}^{-1}$. Farias et al. (2016) used different organic substrates to produce moringa seedlings, and the potassium accumulation obtained was higher than those obtained in this work, possibly this difference in nutrient accumulation is related to the characteristics of each species. The values of calcium obtained in the work were higher than those observed by Navroski et al. (2015) in seedlings of Eucalyptus dunnii. Barros et al. (2013) obtained values inferior to the one in this work when using different organic compounds to produce the seedlings of the yellow passion fruit. Lower calcium values were also obtained by Pozza et al. (2007) in coffee tree seedlings, ranging from 8.7 to $10 \mathrm{~g} \mathrm{~kg}^{-1}$. Oliveira e Hernandez (2008) in eggplant culture on different substrates obtained calcium contents ranging from 8.45 to $17.63 \mathrm{~kg} \mathrm{~kg}$ ${ }^{1}$. Calcium plays an important role in the stabilization of the walls and cell membranes, where it acts as a cementing agent, increasing the resistance to pathogen penetration (Pozza et al., 2007). Pozza et al. (2007), using substrates composed of $80 \%$ corral manure and $20 \%$ subsoil soil, obtained similar results for the coffee crop. Silva et al. (2014) obtained similar results working with jatropha seedlings. 
Reis et al. (2015) evaluated the concentration of leaf sulfur in Dilodendron bipinnatum at different levels of shading and obtained values between 1.78 and $3.26 \mathrm{~g} \mathrm{~kg}^{-1}$. The highest $\mathrm{Mg}$ contents were observed in the aerial parts of $A$. mangium and $A$. auriculiformis plants on the substrates horizon Bw with washed sand and cattle manure and $100 \%$ of sewage sludge (Cunha et al., 2006). Using different commercial substrates in coffee seedlings, Pozza et al. (2007) obtained accumulations of leaf sulfur ranging from 0.5 to $1.2 \mathrm{~kg}^{-1}$, these results are lower than that obtained in this work and Fochesato et al. (2008), which is between 2.67 and $4.63 \mathrm{~g} \mathrm{~kg}^{-1}$ in citrus seedlings. When comparing these results with those of the control, the substrates SIP and Cs increased the leaf contents of $S$ by $57.75 \%$ and $51.17 \%$ (without biofertilizer) and $52.07 \%$ and $42.64 \%$ (with biofertilizer). Sulfur plays an important role in the structure of proteins, being of value in the membranes of cells, in addition to performing important metabolic functions. Its deficiency causes a decrease in photosynthesis and respiratory activity, decrease of protein synthesis, and reduction in fat content, among others (Malavolta, 1980).

\section{Materials and Methods}

\section{Place of study, type of substrates, and experimental design}

The experiment was conducted between the months of August and November in 2015, in a protected environment belonging to the Center for Human, Social and Agricultural Sciences (CCHSA), Federal University of Paraíba (UFPB), Bananeiras-Paraíba, Brazil. The experimental design was a randomized complete block design in a $4 \times 2$ factorial arrangement, with five replications and four plants per experimental unit. The factors corresponded to four types of substrates (W, yellow dystrophic latosol; CS, commercial substrate from the fruit and vegetable remnants of the Paraibana Company of Supply and Agricultural Services (EMPASA); RFV, composed of remnants of fruits and vegetables from the restaurant; SIP, residues of industrialized products from university restaurant meals), in the substrate without and with application of bovine biofertilizer in the substrate. In all the treatments, the substrate ratio of 3:1 (v/v) were inserted, that is, 3 volumes of soil and 1 volume of the compounds mixed for the formation of each treatment. The soil used was collected at a depth of 0 to $20 \mathrm{~cm}$ of a dystrophic yellow latosol, classified according to the criteria of the Brazilian Soil Classification System (SiBCS) (EMBRAPA, 2013). Compounds of fruit and vegetable remains and meal remnants from the university restaurant of CCHSA/UFPB were prepared with the addition of bovine manure for a period of 90 days. This input is noncommercial, called Supermagro biofertilizer that is produced according to the methodology of Penteado (2007). The application of the biofertilizer was carried out via soil 15 days after the emergency (DAE), with a 15-day interval after the first application and a concentration of $5 \%$ of the organic input. The chemical analyses of the fertility of the compounds used and of the biofertilizer are shown in Table 1.

\section{Variables analyzed}

The seeds were collected in plant matrices located in the municipality of Remígio-Paraíba and placed to germinate in polyethylene bags with dimensions of $18 \times 30 \mathrm{~cm}$; after 20 days of sowing, the plants began to emerge lasting up to 25 days. At 90 days after emergence, when the plants were able to be transplanted to the field, analyses of the following biometric variables were performed: caulinar diameter, measured with a digital caliper; plant height with a millimeter in centimeters; dry mass of shoot, root, and totaled by weighing on a semianalytical scale (precision, $>0.001 \mathrm{~g}$ ), and the Dickson quality index was used by following the methodology described by Dickson et al. (1960):

$$
\begin{aligned}
& D Q I=\frac{T D M}{\frac{P H}{S D}+\frac{S D M}{R D M}} \\
& \text { DQI = Dickson Quality Score; } \\
& \text { TDM = Total dry weight }(\mathrm{g}) ; \\
& \mathrm{PH}=\text { Height }(\mathrm{cm}) ; \\
& \mathrm{SD}=\text { stem diameter }(\mathrm{mm}) ; \\
& \mathrm{SDM}=\text { Dry weight of aerial part }(\mathrm{g}) ; \\
& \mathrm{RDM}=\text { Root dry weight }(\mathrm{g})
\end{aligned}
$$

In the same period, the leaves were collected to evaluate the nutritional status of the plants in macronutrients $(\mathrm{N}, \mathrm{P}$, $\mathrm{K}^{+}, \mathrm{Ca}^{2+}, \mathrm{Mg}^{2+}$, and $\left.\mathrm{S}\right)$ in the dry matter of the leaf tissue, using the methodologies suggested by Embrapa (2009). Asepsis of the leaves was done under running water and submerged in deionized water. The material was oven dried at $65^{\circ} \mathrm{C}$ for 72 hours, then comminuted in a Willey TE- $650^{\circ}$ mill, using a 20-mesh sieve.

\section{Statistical analysis of the data}

The data were submitted for the analysis of variance using $F$ test at $5 \%$ probability. The averages for the application of the bovine biofertilizer via leaf were compared using the $F$ test, which, in this case, is conclusive and with substrate composition averages, compared using the Scott-Knott test ( $p<0.05$ ). Statistical analysis was performed using the statistical software ASSISTAT version 7.7 beta (Silva e Azevedo, 2002).

\section{Conclusion}

The use of residues of fruits and vegetables (RFV) and residues of industrialized products (SIP) is recommended for the composition of submetry of pitombeira because it provides greater growth of pitombeira seedlings. The addition of organic residues increases the quality of pitombeira seedlings with higher quality in biofertilizer treatments. The commercial substrate (CS) increased the nitrogen and potassium terrors for the substrates with fruit and vegetable residues (RFV), and the residues of industrialized products (RPI) used for the propagation of pitombeira seedlings can be recommended for the production of seedlings, because they increased the leaf content of phosphorus, calcium, magnesium, and sulfur. 


\section{Acknowledgments}

To the Center for Human Sciences, Social and Agrarian of the Federal University of Paraíba for the support in the development of the research.

\section{References}

Antunes RM, Castilhos RMV, Castilho DD, Leal AO, Andreazza $R$ (2016) Crescimento inicial de acácia-negra com vermicompostos de diferentes resíduos agroindustriais. $\mathrm{Ci}$ FI. 26 (1): 1-9.

Araujo EC, Costa RS, Lopes EC, Daher RF, Fernandes M B (2014) Qualidade das mudas de espécies arbóreas de mangue cultivadas em viveiro e diferentes substratos. Acta Ambient Catarin. 11 (1): 21-31.

Augostinho LMD, Prado RM, Rozane DE, Freitas N (2008) Acúmulo de massa seca e marcha de absorção de nutrientes em mudas de goiabeira 'Pedro Sato'. Bragantia. 67 (3): 577-585.

Barros CMB, Müller MML, Botelho RV, Michalovicz L, Vicensi M, Nascimento R (2013). Substratos com compostos de adubos verdes e biofertilizante via foliar na formação de mudas de maracujazeiro-amarelo. Semina: Ciênc Agrár. 34(6): 2575-2588.

Castro LHS, Assis RT, Nociti LAS, Assis JC, Castro LGS (2012) Formação de mudas de maracujazeiro-amarelo com resíduo agroindustrial do processamento de batata como substrato. Rev Bras Agrocienc. 18(2): 163-174.

Cavalcante ACP, Silva AG, Silva MJR, Araújo RC (2016a) Produção de mudas de Gliricídia com diferentes substratos orgânicos. Rev Agrarian. 9(33): 233-240.

Cavalcante AG, Araújo RC, Cavalcante ACP, Barbosa AS, Diniz Neto MA, Matos BF, Oliveira DS, Zuza JFC (2016b) Production of yellow passion fruit seedlings on substrates with different organic compounds. Afr J Agric Res. 11(12): 1086-1091.

Cunha AM, Cunha GM, Sarmento RA, Cunha GM, Amaral JFT (2006). Efeito de diferentes substratos sobre o desenvolvimento de mudas de Acacia sp. Rev Árvore. 30 (2): 207-214.

Dickson, A; Leaf, AL; Hosner, JF (1960). Quality appraisal of white spruce and white pine seedling stock in nurseries. Forest Chron. 36: 10-13.

Embrapa-Empresa Brasileira de Pesquisa Agropecuária (2009) Centro Nacional de Pesquisa de Solos. Manual de análises químicas de solos, plantas e fertilizantes. $(2 \mathrm{ed})$, Rio de Janeiro, 2009.

Embrapa-Empresa Brasileira de Pesquisa Agropecuária (2013) Solos: Sistema Brasileiro de Classificação de Solos (3 ed), Rio de Janeiro, 2013.

Farias WM, Andrade LA, Albuquerque MB, Cunha JR (2016) Utilização de macrófitas aquáticas em substrato para a produção de mudas de moringa. Pesq Flor Bras. 36 (85): 25-30.

Fochesato ML, Souza PVD, Schäfer G, Maciel HS (2008). Alterações das características químicas de três substratos comerciais na produção de mudas cítricas. Ciênc Agrotec. 32 (4): 1040-1046.

Gonçalves EO, Petri GM, Caldeira MVW, Dalmaso TT, Silva AG (2014). Crescimento de mudas de Ateleia glazioviana em substratos contendo diferentes materiais orgânicos. Floresta Ambient. 21 (3): 339-348.
Kiehl EJ (2010). Novo fertilizantes orgânicos. (1 ed), Piracicaba, 2010.

Kratz D, Nogueira AC, Wendling I, Souza PVD (2015). Substratos renováveis para produção de mudas de Mimosa scabrella. Rev Flor. 45 (2): 393-408.

Jacoby B, Abas S, Steinitz B (1973). Rubidium and potassium absorption by bean-leaf slices compared to sodium absoption. Physiol Plant. 28: 209-214.

Magro FO, Arruda N, Casa J, Salata AC, Cardoso All, Fernandes DM (2010). Composto orgânico na produção e qualidade de sementes de brócolis. Ciênc Agrotec. 34 (3): 596-602.

Malavolta, E (1985). Nutrição mineral. Em: Ferri M G. Fisiologia Vegetal. São Paulo, 1985.

Malavolta, E. (1980). Elementos de nutrição mineral de plantas. São Paulo, 1980.

Melo Filho J S, Araújo DL, Véras MLM, Irineu THS, Andrade R (2015). Interação entre níveis de salinidade e biofertilizante em mudas de pitombeira (Talisia esculenta (a. st.-Hil. Radlk.). Rev Terc Incl. 5 (2): 320-331.

Mesquita FO, Cavalcante LF, Nunes JC, Souto AGL, Medeiros RF, Rodrigues RM (2015). Formação de mudas de nim com aplicação de biofertilizante bovino submetido à drenagem e estresse salino. J Biosci. 31 (1): 47-54.

Navroski MC, Araújo MM, Reininger LRS, Muniz MFB, Pereira MO (2015). Influencia do hidrogel no crescimento e no teor de nutrientes das mudas de Eucalyptus dunnii. Rev Flor. 45 (2): 315-328.

Oliveira AB, Hernandez FFF (2008). Absorção de nutrientes em mudas de berinjela cultivadas em substratos alternativos. Rev Ciênc Agron. 39 (4): 583-589.

Oliveira LR, Lima SF, Lima APL (2014). Crescimento de mudas de cedro-rosa em diferentes substratos. Pesq Flor Bras. 34 (79): 187-195.

Penteado SR (2007). Adubação Orgânica: Compostos orgânicos e biofertilizantes. (2 ed) Campinas, 2007.

Pereira EC, Dantas LLGR, Almeida JPN, Mendonça LFM, Mendonça V (2011). Fontes e doses de nitrogênio na produção de porta-enxertos de pitombeira (Talisia esculenta Radlk). Rev Verde Agroecologia Desenvolv Sustent. 6 (3): 197-202.

Pozza AAA, Guimarães PT G, Pozza EA, Carvalho JG, Montanari M, Souza RF (2007). Efeito do tipo de substrato e da presença de adubação suplementar sobre o crescimento vegetativo, nutrição mineral, custo de produção e intensidade de cercosporiose em mudas de cafeeiro formadas em tubetes. Ciênc Agrotec. 31 (3): 685692.

Prado RM (2008). Nutrição de plantas. (1 ed), UNESP- São Paulo, 2008.

Prezotti LC (2007). Manual de recomendação de calagem e adubação para o estado do Espírito Santo. (5 ed): SEEA/INCAPER/CEDAGRO, 2007.

Rebouças Neto MO, Leite DNP, Campos JR, Veras CL, Souza IR, Monteiro Filho LR (2016). Crescimento inicial do milho sob diferentes concentrações de biofertilizante bovino. Cad Cajuína. 1 (3): 4-14.

Reis SM, Morandi OS, Oliveira B, Oliveira EA, Valadão MBX, Marimon BS, Marimon-Junior BH (2015). Influência do sombreamento no desenvolvimento inicial e eficiência no uso de nutrientes de Dilodendron bipinnatum Radkl (Sapindaceae). Sci Forestalis. 43 (107): 581-590. 
Rocha JHT, Backes C, Diogo FA, Pascotto CB, Borelli K (2013). Composto de lodo de esgoto como substrato para mudas de eucalipto. Pesq Flor Bras. 33 (73): 27-36.

Santos ATL, Henrique NS, Shhlindwein JA, Ferreira E, Stachiw $R$ (2014). Aproveitamento da fração orgânica dos resíduos sólidos urbanos para produção de composto orgânico. Rev Bras Ciên Amazônia. 3 (1): 15-28.

Sena LHM, Matos VP, Medeiros JE, Santos HHD, Rocha, AP, Ferreira R LC (2016) Storage of pitombeira seeds [Talisia esculenta (a. st. Hil) Radlk- sapindaceae] in different environments and packagings. Rev Árvore. 40 (3): 435-445.

Silva IP, Rodas CL, Ferreira ED, Carvalho JG (2014). Crescimento e nutrição de mudas de pinhão manso influenciados pela substituição do potássio pelo sódio. Rev Caatinga. 27 (1):194-199.

Silva FAZ, Azevedo CAV (2002). Versão do programa computacional Assistat para o sistema operacional Windows. Rev Bras Prod Agroind. 4(1): 71-78, 2002.
Soares I, Lima SC, Crisóstomo LA (2007) Crescimento e composição mineral de mudas de gravioleira em resposta a doses de fósforo. Rev Ciênc Agron. 38 (4): 343-349, 2007. Souza MP, Bataglion GA, Silva FMA, Almeida RA, Paz WHP, Nobre TA, Marinho JVN Salvador MJ, Fidelis CHV, Acho LDR, Souza ADL, Nunomura RCS, Eberlin MN, Lima ES, Koolen HHF (2016) Phenolic and aroma compositions of pitomba fruit (Talisia esculenta Radlk.) assessed by LCMS/MS and HS-SPME/GC-MS. Food Res Int. 83: 87-94.

Taiz L, Zeiger E, Moller IM, Murphy A (2017) Fisiologia e desenvolvimento vegetal. (6 ed), Porto Alegre. 2017.

Trazzi PA, Caldeira MVW, Colombi R, Gonçalves EO (2012. Qualidade de mudas de Murraya paniculata produzidas em diferentes substratos. Rev Flor. 42 (3): 621-630.

Vidal LHI, Souza JRP, Fonseca EP, Bordin I (2006). Qualidade de mudas de guaco produzidas em casca de arroz carbonizada com vermicomposto. Hortic Bras. 24 (1): 26 30. 